DOI: https://doi.org/10.24127/ajpm.v10i1.3443

\title{
TIPE PEMBUKTIAN MAHASISWA CALON GURU MATEMATIKA
}

\author{
Mu'jizatin Fadiana ${ }^{1^{*}}$, Yulaikah $^{2}$, Lajianto $^{3}$ \\ $1^{*, 2,3}$ Universitas PGRI Ronggolawe, Tuban, Indonesia \\ ${ }^{*}$ Corresponding author. \\ E-mail: $\quad$ mujizatin000@gmail.com ${ }^{1 *}$
}

Received 31 December 2020; Received in revised form 06 March 2021; Accepted 01 April 2021

\begin{abstract}
Abstrak
Kemampuan pembuktian matematis formal merupakan kemampuan penting yang harus dikuasai calon guru matematika. Namun demikian, mahasiswa calon guru matematika mengalami kesulitan dalam mengkonstruk pembuktian. Oleh karena itu, penelitian ini bertujuan untuk mengeksplorasi kecenderungan metode pembuktian matematika calon guru matematika di perkuliahan Tahun kedua. Metode yang digunakan dalam penelitian ini adalah penelitian deskriptif kuantitatif. Partisipan dalam penelitian ini adalah 30 calon guru matematika di sebuah perguruan tinggi di Tuban, Jawa Timur. Instrumen penelitian berupa tugas sederhana menyusun bukti matematis. Hasil penelitian dianalisis menggunakan klasifikasi tipe pembuktian oleh Miyazaki, yaitu mengklasifikasikan jenis penalaran deduktif dan induktif. Hasil penelitian menunjukkan bahwa calon guru matematika memiliki kecenderungan untuk menggunakan penalaran deduktif yang lebih besar daripada menggunakan penalaran induktif. Pembuktian tipe A adalah pembuktian yang paling banyak ditemukan. Selain itu, sekitar 70\% calon guru masih mengalami kesulitan dalam menyusun tugas pembuktian.
\end{abstract}

Kata kunci: bukti matematis; calon guru matematika; metode pembuktian deduktif-induktif,

\begin{abstract}
The ability to prove formal mathematics is an important ability that must be mastered by undergraduate prospective mathematics teachers. However, students who are prospective mathematics teachers have difficulty in constructing proof in mathematics courses. Therefore, this study aims to explore the tendency of mathematical proof methods for prospective mathematics teachers in second year lectures. The method used in this research is quantitative descriptive research. Participants in this study were 30 prospective mathematics teachers at a tertiary institution in Tuban, East Java. The research instrument is a simple task of compiling mathematical evidence. The results of the study were analyzed using the classification of types of proof by Miyazaki, namely classifying the types of deductive and inductive reasoning. The results showed that prospective mathematics teachers had a greater tendency to use deductive reasoning than using inductive reasoning. Type A proof is the most common type of proof. In addition, around $70 \%$ of prospective teachers still experience difficulties in compiling evidentiary tasks.
\end{abstract}

Keywords: deductive-inductive proofing, mathematical proof, prospective teachers

This is an open access article under the Creative Commons Attribution 4.0 International License

\section{PENDAHULUAN}

Pembuktian merupakan aspek penting dalam matematika karena merupakan komponen utama dalam memahami matematika (Köğce et al., 2010). Oleh karena itu, pembelajaran matematika secara strategis dapat dikembangkan melalui penguasaan pembuktian matematis beserta cara mengkonstruksi bukti (Balacheff, 2010; M. Fadiana, Amin, Lukito, Wardhono, et al., 2019). Pembuktian matematis juga berperan untuk memverifikasi kebenaran suatu hasil atau kebenaran pernyataan, untuk mengkomunikasikan pengetahuan matematika, dan untuk menerapkan sistem aksiomatik (De Villiers, 2010) . Tujuan pembuktian 
adalah membantu menyelidiki kebenaran dan menunjukkan relevansi pembenaran (M. Fadiana, Amin, Lukito, \& Warli, 2019; Lee, 2012). Dengan demikian, kemampuan pembuktian matematis formal merupakan kemampuan penting yang harus dikuasai sarjana calon guru matematika (Mu'jizatin Fadiana et al., 2021; Shaker \& Berger, 2016)

Disebabkan

kemampuan pembuktian secara matematis formal penting bagi calon guru matematika, maka pembelajaran matematika di perguruan tinggi diarahkan pada pengenalan transisi pembuktian atau pengenalan mata kuliah untuk membangun penalaran matematis (Selden et al., 2014; Smith, 2017), yang memfasilitasi mahasiswa calon guru matematika untuk memahami bahasa matematika formal dan struktur aksiomatik. Namun, hal ini tidak mudah untuk dilakukan. Mahasiswa merasa kesulitan dalam mengkonstruksi pembuktian formal. Mahasiswa dituntut untuk mengubah jenis penalaran mereka, misalnya, mengubah bahasa informal ke bahasa formal, penalaran dari definisi matematika, memahami dan menerapkan teorema, dan membuat hubungan antara objek matematika (Corriveau, 2017; Di Martino \& Gregorio, 2019)

Meskipun pembuktian merupakan bagian penting dari matematika di tingkat perguruan tinggi, beberapa penelitian menunjukkan bahwa mahasiswa sering mengalami kesulitan dalam menyusun bukti (Selden et al., 2014). Hal yang sama juga terjadi pada siswa maupun mahasiswa di Indonesia. Beberapa penelitian menunjukan bahwa kemampuan pembuktian siswa, bahkan mahasiswa masih rendah (Siswono et al., 2020). Terdapat $15,83 \%$ dari jawaban pembuktian mahasiswa yang diidentifikasi sebagai jawaban yang benar, sedangkan jawaban yang lain menunjukkan kesalahan terkait konstruksi bukti.

Secara umum, terdapat dua metode pembuktian yang sering digunakan, yaitu deduktif dan induktif (Köğce et al., 2010). Metode pembuktian deduktif meliputi beberapa jenis, yaitu pembuktian langsung, pembuktian dengan kontraposisi, dan pembuktian dengan kontradiksi (Simon, 2020). Metode pembuktian deduktif dalam matematika dimulai dengan pernyataan umum atau hipotesis dan menguji kemungkinan untuk mencapai suatu kesimpulan logis (Miyazaki et al., 2017). Sedangkan metode induktif biasanya sering digunakan oleh siswa sekolah menengah dimana mereka sedang belajar membuktikan proposisi numerik atau geometris (Miyazaki, 2000). Kedua metode ini didasarkan pada jenis-jenis penalaran yang digunakan seseorang dalam melakukan proses pembuktian, yang masingmasing mengacu pada penalaran deduktif dan penalaran induktif.

Penelitian sebelumnya telah mengungkap kemampuan guru dalam pembuktian matematis antara pembuktian secara argumen empiris dan pembuktian deduktif (Knuth, 2002; Morselli, 2006). Dari hasil penelitian ini, ternyata beberapa guru SD prajabatan menggunakan dan menerima argumen empiris sebagai bukti (Sema \& Ispir, 2011). Oleh karena itu, penelitian ini akan mengidentifikasi tentang kecenderungan calon guru matematika dalam mengkonstruk bukti matematika secara formal pada mata kuliah Teori Bilangan, antara pembuktian deduktif dan pembuktian induktif. Hasil identifikasi ini akan memberikan informasi bagi dosen untuk mengembangkan perkuliahan yang 
memfasilitasi mahasiswa calon guru matematika untuk memahami bahasa matematika formal dan struktur aksiomatik. Sehingga calon guru matematika tidak lagi menggunakan dan menerima argumen empiris sebagai bukti matematis.

\section{METODE PENELITIAN}

Penelitian ini menggunakan desain penelitian deskriptif kuantitatif untuk mengidetifikasi jenis penalaran mahasiswa calon guru matematika dalam mengkonstruk pembuktian matematis. Penelitian ini dilakukan di sebuah perguruan tinggi di Tuban, Jawa Timur pada mahasiswa yang sedang menempuh matakuliah Teori Bilangan. Subjek penelitian adalah mahasiswa tahun kedua di salah satu PTS di Kabupaten Tuban Jawa Timur sebanyak 30 orang yang terdiri 9 laki-laki dan 21 perempuan. Pengumpulan data dilakukan dengan memberikan tes awal kepada mereka. Sebelumnya, mereka telah menempuh mata kuliah pengantar dasar matematika. Tes awal berupa tugas sederhana menyusun bukti matematis dari pernyataan berikut:

Soal nomor 1: Jumlah dari dua bilangan ganjil adalah bilangan genap.

Soal nomor 2: Jika a adalah bilangan genap dan $b$ adalah bilangan ganjil, maka $a^{2}+b^{2}$ adalah bilangan ganjil

Tugas sederhana ini terdiri dari pertanyaan yang meminta mahasiswa calon guru matematika untuk menyusun pembuktian sesuai dengan jenis penalarannya. Setiap calon guru diberi waktu 30 menit untuk menyelesaikan tugas. Setelah itu, jawaban dari setiap calon guru diidentifikasi untuk mengetahui pemahaman calon guru atas pengetahuan deduktif dan induktif dalam menyusun bukti. Jawaban calon guru dianalisis dengan menggunakan klasifikasi Miyazaki (2000) tentang jenis pembuktian matematis sebagaimana dapat dilihat pada Tabel 1

Tabel 1. Jenis pembuktian matematis oleh Miyazaki (2000)

\begin{tabular}{|c|c|c|}
\hline \multirow[b]{2}{*}{ Representasi } & \multicolumn{2}{|c|}{ Jenis Penalaran } \\
\hline & $\begin{array}{c}\text { Penalaran } \\
\text { Induktif }\end{array}$ & $\begin{array}{c}\text { Penalaran } \\
\text { Deduktif }\end{array}$ \\
\hline $\begin{array}{l}\text { Menggunakan } \\
\text { representasi } \\
\text { bahasa } \\
\text { fungsional }\end{array}$ & Bukti D & Bukti A \\
\hline $\begin{array}{l}\text { Menggunakan } \\
\text { representasi }\end{array}$ & Bukti C & Bukti B \\
\hline $\begin{array}{l}\text { bahasa lain, } \\
\text { gambar, atau } \\
\text { objek lainnya }\end{array}$ & & \\
\hline
\end{tabular}

Miyazaki (2000) mengklasi-
fikasikan bukti menjadi empat bukti B, tipe bukti C, dan tipe bukti D. Menurut Miyazaki, Bukti A adalah tipe bukti dimana melibatkan penalaran deduktif dan bahasa fungsional dalam melakukan pembuktian. Bukti B adalah jenis bukti dimana menggunakan penalaran deduktif dan bahasa lain, gambar dan objek lainnya dalam melakukan pembuktian. Bukti $\mathrm{C}$ adalah jenis pembuktian yang bersifat melibatkan penalaran induktif dan bahasa lain, gambar dan objek yang lain. Bukti D adalah jenis pembuktian yang menggunakan penalaran induktif dan bahasa fungsional.

\section{HASIL DAN PEMBAHASAN}

Pada bagian ini, data yang diperoleh dari peserta dianalisis berdasarkan klasifikasi Miyazaki (2000) kemudian disajikan seperti Tabel 1. 
DOI: https://doi.org/10.24127/ajpm.v10i1.3443

Tabel 1. Frekuensi dan persentase tingkat pembuktian mahasiswa untuk soal nomor 1

\begin{tabular}{ccc}
\hline Tipe Bukti & Frekuensi & Persentase \\
\hline A & 19 & $63.3 \%$ \\
B & 2 & $6.67 \%$ \\
C & 3 & $10 \%$ \\
D & 6 & $20 \%$ \\
\hline
\end{tabular}

Berdasarkan Tabel 1 untuk soal nomor 1 , terdapat $63,3 \%$ calon guru matematika melakukan pembuktian tipe A. Pembuktian tipe A menggunakan penalaran deduktif dan bahasa fungsional untuk mengkonstruk bukti. Sedangkan 6,67 \% calon guru matematika menggunakan pembuktian tipe B, yaitu pembuktian dengan menggunakan penalaran deduktif dan memanipulasi objek atau menggunakan kalimat tanpa bahasa fungsional sebagai pembuktian. $\quad 10 \%$ calon guru matematika menggunakan bukti tipe $\mathrm{C}$ dimana mereka menggunakan penalaran induktif dan bahasa lain, gambar, dan objek yang dimanipulasi untuk mengkonstruk bukti. Selain itu, $20 \%$ calon guru menggunakan bukti D. Mereka menggunakan penalaran induktif dan bahasa fungsional untuk mengkonstruk bukti.

Tabel 2. Frekuensi dan Persentase Tingkat Pembuktian Mahasiswa untuk Soal Nomor 2

\begin{tabular}{ccc}
\hline Tipe Bukti & Frekuensi & Persentase \\
\hline A & 17 & $56,67 \%$ \\
B & 2 & $6,67 \%$ \\
C & 7 & $23,3 \%$ \\
D & 4 & $13,3 \%$ \\
\hline
\end{tabular}

Tabel 2 menggambarkan bahwa $56,67 \%$ calon guru matematika melakukan pembuktian tipe A, yaitu menggunakan penalaran deduktif dan bahasa fungsional untuk mengkonstruk bukti. Terdapat $6,67 \%$ calon guru matematika menggunakan pembuktian tipe B. Mereka menggunakan penalaran deduktif dan memanipulasi objek atau menggunakan kalimat tanpa bahasa fungsional sebagai pembuktian. Sedangkan ada 23,3 \% calon guru matematika menggunakan bukti tipe $\mathrm{C}$ dimana mereka menggunakan penalaran induktif dan bahasa lain, gambar, dan objek yang dimanipulasi untuk mengkonstruk bukti. Selain itu, 13,3 \% calon guru menggunakan bukti D. Mereka menggunakan penalaran induktif dan bahasa fungsional untuk mengkonstruk bukti.

Adapun mengenai kebenaran jawaban calon guru terhadap soal nomor 1, penelitian ini menemukan bahwa $33,33 \%$ calon guru sudah benar dan $66,67 \%$ calon guru masih mengalami kesulitan dalam menyusun tugas pembuktian untuk soal nomor 1 . Sedangkan untuk soal nomor 2, 26,67 \% calon guru sudah benar dan 73,33\% masih mengalami kesulitan dalam mengkonstruk bukti. Gambar-gambar berikut menjelaskan contoh hasil pembuktian calon guru berdasarkan tipe-tipe pembuktian, yaitu Pembuktian A, Pembuktian B, Pembuktian C, dan Pembuktian D.

Gambar 1 menunjukkan bahwa jawaban pembuktian calon guru matematika benar. Jawaban yang benar dalam pembuktian termasuk pembuktian tipe A, yaitu menggunakan penalaran deduktif dan bahasa fungsional. Penalaran deduktif ditunjukkan dengan pemikiran calon guru matematika yang terlebih dahulu memisalkan bilangan genap dan bilangan ganjil dengan simbol yang berbeda-beda. Hal ini menandakan bahwa ia paham terhadap simbol-simbol matematika yang selanjutnya dimanipulasi dalam proses pembuktian. Selain itu, ia juga menunjukkan 
beberapa bahasa fungsional dengan tepat, seperti simbol $\in$ dan $\mid$ yang jumlah dari dua bilangan

Bukti :

bilangan genap $=2 n, n \in$ Bil. bulat

bilangan ganjil $=2 n-1, n \in$ Bil. bulat

bilangan genap $\rightarrow 2 / 2 n$

Jumlah dua bilangan ganjil $\rightarrow$ bilangan genap

$(2 n-1)+(2 n-1)=2 n+2 n-1-1$

$=4 n-2$

$=2(2 n-1)$, sehingga $2 \mid 2(2 n-1)$

$2 / 2(2 n-1) \rightarrow$ akibatnya jumlah dua bilangan ganjil. adalah bilangan genap

Gambar 1. Contoh dari pembuktian tipe A

Jumlah dari dua bilangan ganjil adalah bilangan genap

Pembuktian:

Jika $n$ adalah bilangan ganjil, maka $n+n=2 n$.

$2 n$ adalah bilangan genap. Dari hal tersebut dapat

dinyatakan bahwa dua buah bilangan ganjil apabila dijumlah hasilnya adalah bilangan genap.

Gambar 2. Contoh dari pembuktian tipe B

Gambar 2 menunjukkan bahwa calon guru matematika melibatkan penalaran deduktif tetapi tidak sepenuhnya menggunakan bahasa fungsional dalam menyusun pembuktian. Ia menggunakan bahasa fungsional dan non fungsional. Ia juga tidak bisa menyatakan definisi dengan benar seperti yang ditunjukkan dalam definisinya "n adalah bilangan ganjil". Ia tidak bisa membuktikan bahwa " $2 \mathrm{n}$ adalah bilangan genap". Sehingga, ia melakukan pembuktian secara tidak tepat.
Gambar 3 menggambarkan bahwa calon guru matematika menggunakan penalaran induktif tetapi tidak melengkapi pembuktiannya. Dia lebih cenderung menyebutkan beberapa bilangan pada operasi aritmatika, yaitu $4^{2}+7^{2}$ dan $2^{2}+3^{2}$, tetapi tidak menyimpulkan contoh pembuktian ke bentuk umum dimana merupakan bahasa fungsional yang digunakan dalam menyusun pembuktian. 


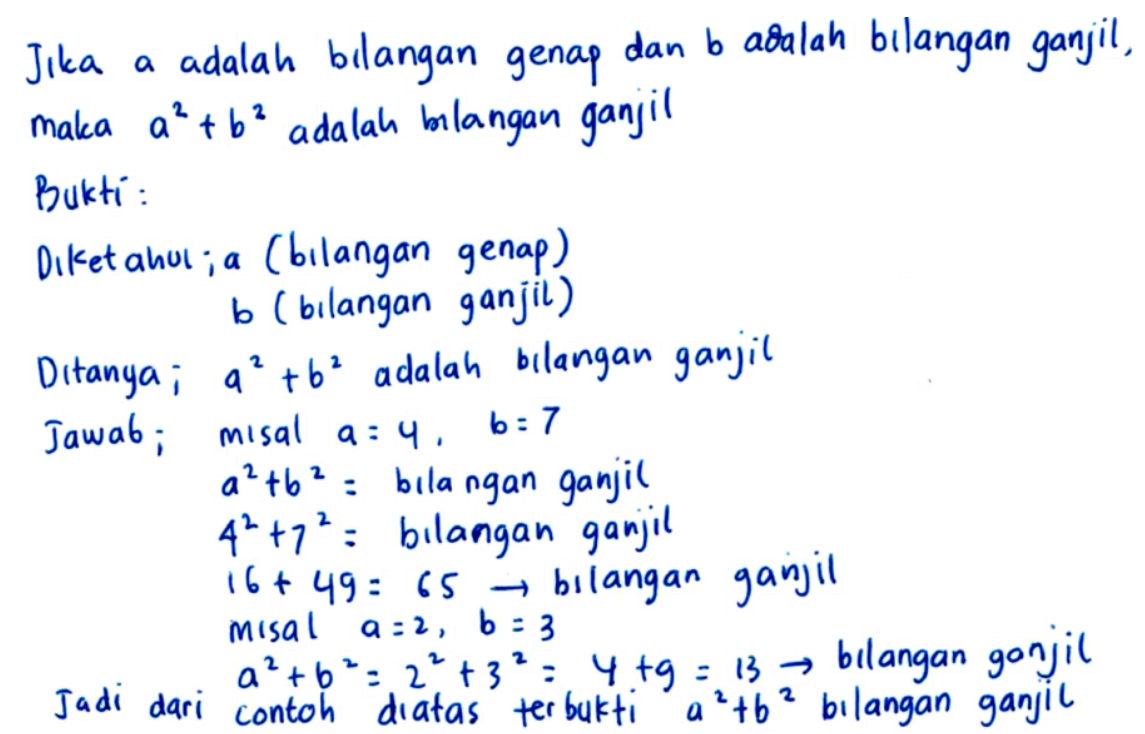

Gambar 3. Contoh dari pembuktian C

\begin{abstract}
Hasil penelitian menunjukkan bahwa calon guru matematika menerapkan metode deduktif dan induktif dalam mengkonstruksi pembuktian. Metode deduktif terdiri dari dua tipe yaitu tipe bukti A dan tipe bukti B. Sedangkan metode induktif terdiri dari dua tipe yang tipe bukti $\mathrm{C}$ dan tipe bukti D. Tabel 1 menunjukkan bahwa $70 \%$ calon guru menggunakan metode deduktif sedangkan $30 \%$ di antaranya menggunakan metode induktif. Sedangkan dari Tabel 2, 63,34 $\%$ calon guru matematika menggunakan metode deduktif dan sisanya menggunakan metode induktif. Dari kedua tabel memberi arti bahwa lebih dari separuh jawaban calon guru matematika menggunakan metode deduktif. Meskipun beberapa calon guru mengalami kesalahan dalam menyusun pembuktian, namun mereka sudah mencoba menyusun pembuktian dengan metode deduktif. Hasil penelitian ini sejalan dengan penelitian Miyazaki (2000) bahwa sebagian besar siswa menggunakan metode deduktif daripada induktif dalam menyusun pembuktian. Hasil penelitian ini juga sejalan dengan penelitian Siswono et al., (2020) yang
\end{abstract}

juga menyebutkan bahwa mahasiswa calon guru lebih banyak menggunakan metode deduktif dalam mengkonstruk bukti. Jika dibandingkan dengan hasil penelitian yang dilakukan oleh Köğce et al., (2010), hal ini tidak sejalan dengan hasil Köğce et al., (2010), dimana hasil penelitiannya melaporkan bahwa pembuktian $\mathrm{C}$ dilakukan oleh sebagian besar siswa dibandingkan jenis pembuktian lainnya. Kenyataan pada penelitian ini menunjukkan bahwa metode deduktif lebih banyak digunakan oleh calon guru matematika. Kemungkinan karena tugas pembuktian yang diberikan dalam penelitian ini menuntut pemecahan dengan menggunakan metode deduktif daripada metode induktif.

Mengenai kebenaran jawaban calon guru matematika terhadap soal nomor 1 , penelitian ini menemukan bahwa $33,33 \%$ calon guru sudah benar dan $66,67 \%$ calon guru masih mengalami kesulitan dalam menyusun tugas pembuktian untuk soal nomor 1 . Sedangkan untuk soal nomor 2, 26,67\% calon guru sudah benar dan 73,33\% masih mengalami kesulitan dalam mengkonstruk bukti. Fakta ini tidak 
sejalan dengan penelitian Demiray \& Işıksal Bostan (2017) yang melaporkan bahwa sebagian besar bukti siswa yang tidak lengkap menghasilkan bukti, akibatnya hasil jawaban mereka salah.

Penelitian ini hanya difokuskan untuk mengetahui kecenderungan penalaran yang digunakan oleh mereka dalam mengkonstruksi pembuktian. Hasil penelitian ini menunjukkan bahwa pilihan mahasiswa calon guru untuk menggunakan metode induktif maupun deduktif dipengaruhi oleh pemahaman mereka terhadap pernyataan yang akan dibuktikan. Kemampuan memahami bukti matematis berpengaruh terhadap kemampuan siswa dalam mengonstruksi bukti matematis. Hasil ini memberikan informasi penting bagi dosen dalam mengembangkan perkuliahan yang memfasilitasi mahasiswa calon guru matematika untuk memahami bahasa matematika formal dan struktur aksiomatik.

\section{KESIMPULAN DAN SARAN}

$\begin{array}{ccr}\text { Calon } & \text { guru } & \text { matematika } \\ \text { mengkonstruk } & \text { bukti } & \text { dengan }\end{array}$ menggunakan penalaran deduktif dan penalaran induktif. Penalaran deduktif lebih banyak dipakai oleh mereka daripada penalaran induktif. Pembuktian A merupakan tipe terbanyak yang digunakan oleh calon guru matematika, yaitu pembuktian dengan metode deduktif dan bahasa fungsional. Meskipun demikian, beberapa calon guru masih mengalami kesulitan dalam menyusun pembuktian matematis.

Bagi peneliti yang tertarik dalam pembuktian matematika, dapat meneliti tentang tipe-tipe kesalahan mahasiswa calon guru dalam mengkonstruksi pembuktian sebagai pengembangan dari hasil penelitian ini.

\section{DAFTAR PUSTAKA}

Balacheff, N. (2010). Bridging knowing and proving in mathematics: A didactical perspective. In Explanation and Proof in Mathematics: Philosophical and Educational Perspectives. https://doi.org/10.1007/978-1-44190576-5_9

Corriveau, C. (2017). Secondary-totertiary comparison through the lens of ways of doing mathematics in relation to functions: a study in collaboration with teachers. Educational Studies in Mathematics. https://doi.org/10.1007/s10649-0169719-2

De Villiers, M. (2010). Experimentation and proof in mathematics. In Explanation and Proof in Mathematics: Philosophical and Educational Perspectives. https://doi.org/10.1007/978-1-44190576-5_14

Demiray, E., \& Işıksal Bostan, M. (2017). An Investigation of Pre-service Middle School Mathematics Teachers' Ability to Conduct Valid Proofs, Methods Used, and Reasons for Invalid Arguments. International Journal of Science and Mathematics Education.

https://doi.org/10.1007/s10763-0159664-Z

Di Martino, P., \& Gregorio, F. (2019). The Mathematical Crisis in Secondary-Tertiary Transition. International Journal of Science and Mathematics Education. https://doi.org/10.1007/s10763-0189894-y

Fadiana, M., Amin, S. M., Lukito, A., Wardhono, A., \& Aishah, S. (2019). Assessment of seventh grade students' capacity of logical thinking. Jurnal Pendidikan IPA Indonesia, $\quad 8(1), \quad 75-80$. https://doi.org/10.15294/jpii.v0i0.11 644 
Fadiana, M., Amin, S. M., Lukito, A., \& Warli. (2019). How concrete operational student generalize the pattern?: Use semiotic perspective. Journal of Physics: Conference Series. https://doi.org/10.1088/17426596/1188/1/012032

Fadiana, Mu'jizatin, Amin, S. M., Lukito, A., Yuliastuti, R., \& Apriono, D. (2021). Pattern Generalization Strategy From Concrete Operational Students. Journal of Physics: Conference Series. https://doi.org/10.1088/17426596/1776/1/012019

Knuth, E. J. (2002). Secondary school mathematics teachers' conceptions of proof. Journal for Research in Mathematics Education, 33(5), 379405.

https://doi.org/10.2307/4149959

Köğce, D., Aydin, M., \& Yildiz, C. (2010). The views of high school students about proof and their levels of proof (The case of Trabzon). Procedia - Social and Behavioral Sciences, 2(2), 2544-2549. https://doi.org/10.1016/j.sbspro.2010 .03 .370

Lee, K. (2012). Students' logical reasoning and mathematical proving of implications. Dissertation Abstracts International Section A: Humanities and Social Sciences, 72(8-A), 2680.

Miyazaki, M. (2000). Levels of Proof in Lower Secondary School Mathematics. Educational Studies in Mathematics.

https://doi.org/10.1023/A:10039565 32587

Miyazaki, M., Fujita, T., \& Jones, K. (2017). Students' understanding of the structure of deductive proof. Educational Studies in Mathematics. https://doi.org/10.1007/s10649-0169720-9

Morselli, F. (2006). Use of Examples in Conjecturing and Proving: an
Exploratory Study. Proceedings of the 30th Conference of the International Group for the Psychology of Mathematics Education.

Selden, J., Benkhalti, A., \& Selden, A. (2014). An analysis of transition-toproof course students' proof constructions with a view towards course redesign. Proceedings of the 17 Th Annual Conference on Research in Undergraduate Mathematics Education, SEPTEMBER 2014, 246-259.

Shaker, H., \& Berger, M. (2016). Students' difficulties with definitions in the context of proofs in elementary set theory. African Journal of Research in Mathematics, Science and Technology Education, 20(1), 80-90. https://doi.org/10.1080/10288457.20 16.1145449

Simon, M. A. (2020). Reconstructing Mathematics Pedagogy from a Constructivist Perspective. Journal for Research in Mathematics Education.

https://doi.org/10.5951/jresemathedu c.26.2.0114

Siswono, T. Y. E., Hartono, S., \& Kohar, A. W. (2020). Deductive or inductive? prospective teachers' preference of proof method on an intermediate proof task. Journal on Mathematics Education, 11(3), 417438.

https://doi.org/10.22342/jme.11.3.11 846.417-438

Smith, S. (2017). An Exploratory Study of Fifth-Grade Students ' Reasoning About the Relationship Between Fractions and Decimals When Using Number Line-Based Virtual Manipulatives. 